\title{
SUSTAINABLE LIVING MODELS
}

\author{
M.L. DELENDI \\ Architect, PhD, Polytechnic Department of Engineering and Architecture of the University of Udine.
}

\begin{abstract}
The evolution of environmental awareness can be traced from the start of the 1960s until date. The evolution embraces social and economic needs that have led us to explore new living strategies. These new sharing living models, which in truth have taken root in older traditions, can become efficient urban and territorial redesigning devices for recovering the heritage of existing buildings as well as disused and abandoned areas on a sustainability basis. The main characteristics of eco-neighbourhoods, cohousing and eco-villages are considered in this sense. These experiences turn out to be a possibility for the development of forms of sustainable living, differently presented, where a conscious ethical choice is at the base of reciprocal respect, tolerance and sharing of common goods.

Keywords: cohousing, eco-villages, living models, sustainability.
\end{abstract}

\section{INTRODUCTION}

With a short historical overview I would like to introduce the coordinates within which this study takes place. Soon after World War II, in particular, from the 1960s, a progressive and new attitude took on towards the surrounding environment, a second wave of environmental concern: the first in fact can be referred to the first industrialisation period of the nineteenth century and the first studies and environmental hygiene measures that would then be translated into concrete actions and new plans for the city, which I have already tried to explained in a wider context [1]. The second wave includes different reasons that I have summarised in two manifesto books: the first on anthropological studies on the conditions of life in cities by Jane Jacobs [2] and the second on biological studies relating to the devastating effects of modern cultivation methods on the environment by Rachel Carson [3]. In addition, studies on urban ecology, whose origin I have previously tried to outline [4], have emerged. Therefore, on the whole, a new environmental awareness took shape and the consequences of human actions - that like boomerangs returned to hit humanity which should have benefitted from them - became quite clear. In the 1970s, considerations on a wider scale led to an entirely new concept of the 'limits of growth' [5,6]. We are still dealing with this concept [7] that gave rise to different points of view on the meaning of sustainability and how it can be applied $[8,9]$. Nature is no longer something to be exploited and conquered, 'and over which we have considerable power thanks to technology, but we now interrogate ourselves on how we can relate to it: from the fear of Ulrich Beck's 'risk society' [10] to Hans Jonas's appeal to the imperative of responsibility [11], to the different positions on the social systems theories [12]. Along with all this, we must bear in mind the global economic situation, a crisis that calls for new growth models. What has emerged from recent discussions and debates with a new generation of economists [13] is the need for new building scenarios to break the rigid schemes, new bottom up revolutions that peacefully revolutionise stratified economic 
schemes. These are new society models with different economic models. Simultaneously, the green economy and sharing economy phenomena are born as a solution to the environmental and economic crises; it is, therefore, as though the need for a new structure and procedures has emerged to prevent the collapse of our civilisation. In this article we shall try to understand, in a perspective of sustainability and interruption of land consumption, how the different existing models can be taken into consideration for the 'alternative' residential recovery of the dismissed areas and buildings.

\section{SUSTAINABLE ALTERNATIVES TO LAND CONSUMPTION}

Now, with regards to our discipline, besides the environmental attention given to a more liveable city through a 'therapeutic' view that will include the care for public areas, the widespread presence of green infrastructures I have already written about and already being dealt with by the scientific community [14-17], in this work I would like to examine alternative methods of living in the sustainable city; new living methods that are already being experienced as an answer to the economic, environmental and social crises.

I will, therefore, presume the inclusion of these interventions in an urban and territorial system that focuses on liveability, quality and sustainability of interventions regarding practicability and public areas, the creation of road networks and not of isolated operations, the connectivity and the interrelationship of the networks with special care to the green infrastructures and their articulations as already shown in the European programmes and in specialised conferences in Italy [17].

Therefore, zooming in on the disused areas makes it necessary to remember the need for connections to the wider networks. Disused areas make it possible to carry out new experiments and rebuild the community dimension at a local level on a specific site, and are areas that also need to be revamped through sustainable and residential activities that can be contextualised in a territorial planning programme such as, for example, the Coulee Verte in Paris.

The potentials therefore regard both the reuse of disused areas and the requalification of existing heritage through cohousing initiatives [18].

For this reason I found it interesting to explore three living categories by observing their respective characteristics and differences so as to extrapolate possible models of eco-sustainable urban settlements: eco-neighbourhoods, cohousing and eco-villages.

\section{ECO-NEIGHBOURHOODS, COHOUSING AND ECO-VILLAGES}

The examples of eco-neighbourhoods in recovered disused areas are many and have already been tested at this point. The primary steip is to implement a series of devices for energy saving, rainwater harvesting and production of alternative energies. The examples and studies are numerous, and their advanced and wider concept seems to be eco-districts [19].

At this point, the next and more interesting step is that of exploring the experiences of cohousing and eco-villages as a different model in the context of living. Communes of the 1970s are surely not benchmarks for cohousing. If at all, reference is made to the community realities of an agricultural Europe, districts, courts and farmsteads where a well, an oven and a washhouse were often shared, or to the same old definition of neighborhood: the famous 'neighbourhood unity', missed for decades, especially among architects and town planners. And that was thought to be permanently buried with the reflux of the 1980s and the domination of the 'independent freestanding houses' in the outskirts. It has been accurately noted that 'The territory that is drawn from these new «secessionist» attitudes is far from the 
functionalist imperatives, as it is far from those of sprawl. It is rather the outcome of new colonisations of bad lands. Thus, recovery, redemption and recycling become the central issues also in the sharing practices, contributing to reshape the change of values that the European society attributes to dwelling. Their recurrence shatters in a single stroke many rhetorics of the recent years discourse on the city: the value of proximity, the sprawl, the happiness of living every man for himself'. [20] There is rather a return and continuation of the tradition of shared housing, although in a different way [21].

Cohousing can be similar to eco-neighbourhood when it considers energy sustainability, and in this case becomes eco-cohousing. This, however, is not its essential requirement; in fact, it is but a possibility that plays on the research of an alternative social model rather than on ethical-environmental requirements. The cohousing model where various families share common house spaces, therefore implies the 'evolved' concept of family where a family opens up to other families eliminating limits, maximising sharing and occasions of selfmanagement. The effects of these models is economic and energy sustainability, as costs of common services are shared: 'a particular form of neighbourhood where private houses and shared services are combined in such a way as to protect each individual's privacy and at the same time the need for sociality, while offering an efficient solution to everyday living problems. [...] So it is something more than just the traditional condominium, where every owner is locked up inside his own unit, and something less than a community or eco-village where all the members are united by the deep sharing of a common life project which cohousing usually lacks, where every single family has its own domestic economy and pursues its own vision of life' [22].

In fact, in the case of eco-villages, the search focuses on a fundamentally alternative community life that usually also searches for alternative sustenance and self-management methods. The difference lies in the pursuit of methods of achieving energy and food selfsufficiency, nurturing a model of community and shared life, which, in most cases, refers to the model of deep ecology.

\subsection{Alternative social models}

Cohousing was apparently conceived in 1964, when a Danish architect, Jan Gødmand Høyer, traced his path towards the construction of what would become, in 1972, the Skråplanet community. Starting from the 1970s, this type of settlement began to expand in countries of Northern Europe, and more specifically in Denmark, the Netherlands and the Scandinavian republics, and remained restricted to the northern-European context up to the 1980s, when it also caught on in the United States, though with a few specific contextual details. For a rapid excursus, we can mention Wandelmeent, a community born in the Netherlands in 1977; a village with over 50 families sharing the kitchen, bar, fitness centre, laboratories, laundry, recreation room etc. In 1980, Stolplyckan was built in Linkoping: the biggest Swedish cohousing system. It consisted of 2,000 square metres of shared spaces with dining room and industrial kitchen, sports centre, laboratories, music hall, billiard, bar and two guest units. And so, continued on to Denmark and Germany. In the 1980s, this practice spread to the United States and Australia. Presently, many projects are in progress in our country, even as solidarity condominiums and the interest of researchers are based on the possibility of requalifying obsolete buildings thanks to common living experiences [23].

The advantages of 'living together' fall into three categories [24]. Energy and environmental sustainability: common and private spaces are supplied with clean energy, and 
sharing helps enact good practices of recycling and abatement of wastefulness thus facilitating an environmentally friendly living management. Economic sustainability: sharing part of one's own life also helps to share the costs, for example, of food as in easily organising solidarity-based purchasing groups. By increasing the quantities and orders, savings are guaranteed. In the same way, the common spaces make it possible to enjoy a fitness centre, play room, large basement rooms and last-generation household appliances. Social sustainability: learning to live with others and building a strong group identity, learning to make the best decisions in the name of common well-being. One feels less alone being part of a group that has no hierarchical structure. It is essential to have a common and very clear project: it will help overcome some of the normal difficulties encountered in putting together different minds. However, it is possible: those already part of it, guarantee that cohousing improves lifestyle.

The model can be applied not only to urban or suburban sites but also to disused buildings in urban settings. Requirements include the central position and vicinity to transport network. Groups of families and also of singles are created and bound together by common interests.

In London, for example, in a disused skyscraper of abandoned offices covering 1,100 square metres, an important cohousing structure, The Collective, will accommodate students and young people in search of their first job. About 100 residents right in the centre of the town living at affordable prices and sharing common services: library with study room, private garden, fully furnished kitchen, wellness centre and theatre. Savings are estimated to be from $15 \%-40 \%$ [25].

In Italy, different associations (among which are Cohousing, CoAbitare, Ecohousing) act as brokers and facilitators between families and building companies to promote eco-sustainable, urban and rural projects with energy class A.

In Milan, the Cohousing group [24] offers a team of young professionals at the service of families and developers for the design of cohousing settlements. In Milano, the CO22 project is located in the centre of the city with all the district facilities and services at hand, with tram and subway lines, in a redesigned Liberty style building, with 4 staircases and 50 apartments. Here, the intention is to combine environmental, economic and social sustainability. Therefore: (1) requalify the buildings by reducing the energy needs and $\mathrm{CO}_{2}$ emissions to the minimum; (2) promote economic sustainability as the price is lower than the market price. In addition, the cost per square metre of the cohousing unit also includes all the common indoor and outdoor spaces that have already been furnished; (3) promote social sustainability as common well-being is a value, and collaboration, reciprocal respect and creative comparison are functional and necessary to achieve wellbeing and a good quality of life. The persons are guided by a facilitator who leads them to collaborate, work and design together. Common well-being is a value to use and love and respect becomes of fundamental importance so that this way of living becomes different from the traditional one.

If for young people there is no concept of private property, in this case the social composition that adhered to the project is an exact image of contemporary society. The CO22 Cohousing project was presented in Milan [24] and from the preliminary survey, or feasibility project, the following data emerged: 48 couples (24.6\%), 45 families with 3 members $(23.1 \%), 26$ families with 4 members $(13.3 \%), 8$ families with 4 members + elderly $(4.1 \%)$, 65 single members (33.3\%), 3 families of other type (1.5\%). The age range also included a social-mix, from very young to senior citizens. Over half were freelance professionals, followed by teachers, pensioners, researchers, entrepreneurs and artists. 
Spaces requested varied, and most required houses with three rooms $(40.7 \%)$, then four rooms (23\%), two rooms (17.7\%), two small rooms (8.5\%), and over $120 \mathrm{~m}^{2}(9.9 \%)$.

The requests were for common areas regard childcare, elderly care and guest spaces to reduce square meters and thereby save on private spaces. Other requests were for outdoor green areas and conviviality, work, study and creativity spaces, common mobility spaces, for car sharing and bike sharing, and then areas for co-working, like a music hall, arts room and computer room. In addition, technical spaces for hobbies, cellar, laundry/ironing room and mechanics areas for small repairs. Spaces for solidarity-based purchasing group and for sports and wellness were also requested.

In Italy, tens of thousands of people have already subscribed to the cohousing website. The group mainly deals with finding available areas and conducts the feasibility study. In this case, the property belonged to the municipality of Milan transferred as contribution to the fixed assets that were then transferred to the banks that must now place these assets back into circulation.

Groups may also be formed autonomously. For example, Rome is seeking through the Web for adhesions for cohousing groups: the requests are for a central area in the city where urban cultural services and activities can be easily reached on foot. The identification of the building as well as the design of the private and common spaces will be decided by a group of participants in the project. Therefore, common spaces and informed participated design which tend to recreate a true 'neighbourhood unity', with effective economic advantages: the exchange of 'do-it-yourself' services and skill sharing, baby-sitting, dog-sitting shared in common spaces, bike-sharing, car-sharing and laundries. Social needs imply the creation of alternative spatial models that are inspired by well-known models characterised by a great technical and typology variability and flexibility that can be translated into different types of living [18].

\subsection{Alternative spatial models}

The solutions may range from high-tech to low-tech, and choices may even be the most drastic. In the case of $\mathrm{CO} 22$, by eliminating cars courtyards have become spaces where social life can develop, existing public transport is used, alternative means of transport are promoted with the use of bicycles and charging stations for electric cars have been installed. By focusing on people care, the spaces within the courtyards become a safe meeting point for children to play, a green area where small daily activities can be attended to with special care like picking basil, pumping a bicycle tire and so on since they are safe and equipped places for children, guests and the elderly.

In this high-tech case, the buildings are totally supplied with electricity to offer greater efficiency by lowering consumptions and dangers: the all-electric system model increases efficiency, allows home automation controls and is advantageous in terms of maintenance costs. For external wall insulation, to reach class A, photovoltaic panels are installed on roofs and solar greenhouses: verandas with features that make it possible to accumulate heat in winter, and LEDs for energy saving. Rainwater can be harvested for watering the common green areas. Use of certified environmentally friendly materials for interiors hence require a strict selection of suppliers. Photocatalytic concretes are used for exteriors. High-speed digital connections can be used to solve everyday problems, from the management of common spaces to making daily activities easier, as well as the isolation of the wireless stations, disconnection of devices in stand-by to save consumptions, and reduction of magnetic fields where people sleep. 
The spatial models on lot go from single-family homes, to terraced houses, to clusters. Though the last two types offer an indisputable energy advantage thanks to the sharing of the side walls, the purpose is however to form a neighbourhood unit that clusters around the spaces of the large common house where shared services are provided. For this reason, the dimensions of the private houses are reduced and larger dimensions will be found in the common spaces. The cohousing settlement consists of a small number of houses, from 15 to 40, with a number of people ranging from a minimum of 15-20 to a maximum of 90-100, which is the number considered most suitable for the creation of a cohesive community. The sharing of common services requires the participated design and their corporate management. In general, there are traditional design requirements such as: good visibility of all the common spaces, external parking areas, gradual transition from public, semi-public and private space, buffer zones for socialisation and shared pedestrian paths; this leads to the configuration 'of an introverted settlement' of houses lined or clustered around a central common space so as to guarantee accessibility and surveillance [23, 26-28].

\subsection{Eco-villages}

Though the eco-villages can be considered as a form of cohousing, they differ from these as they are a form of living that is alternative to the system: they rise in rural zones where the direct relationship with nature is the main attraction. Here, community management is a more intense experience than in cohousing because a 'modus vivendi' is chosen and shared with other people, assuming that a common culture orients the 'intentional community' of the ecovillage [29]. It is the sharing of ethical, spiritual, ecological and social values characterised by the choice of an environmental low-impact life that is in harmony with nature. An international network includes all continents (GEN, Global Ecovillages Network) and the Italian network RIVE (Rete Italiana Villaggi Ecologici: Italian Network of Ecological Villages) [30]. Due to the characteristics of the eco-village, a requalification experience of the disused areas is difficult because of the poor environmental quality that these sites present, though it should not be excluded. All the communities are characterised by personal growth, total respect towards the natural elements with forms of self-production of local organic food, biodynamic and permaculture or zero-mile farming methods. All are recovered in sustainable building by promoting renewable energies for as much as it is possible to achieve energy self-sufficiency.

Although the concept of eco-village has been experimented on communities since the 1970s, many have only been established recently (in the past 10 years) and overall the children from these communities seem to maintain the institution of the traditional family in a setting of reciprocal community support. The weaker categories are those that mostly draw benefit from the close-knit living style: the elderly find occasions to socialise and become helpful to others, and children grow up with many different role models who complete and supplement the parental scene.

The spaces are organised inside villages, abandoned farmsteads that are renovated and expanded, and small farms with new buildings usually built following sustainable building criteria. There are no restrictions in this sense but it is the same ethical force of the idea that leads to shared choices.

\section{CONCLUSIONS}

Shared living is already a form of living that has been tested in its different forms: from the sustainable condominium to the obsolete historical and modern buildings that have been 
redesigned, to disused service structures such as former factories or markets that are refunctionalised with the aim of sustainably recovering and sharing goods and services, up to the recovery of historical villages and small farms in the low environmental impact experiences of the eco-villages.

This movement can be managed by associations that facilitate the relationship between the building companies and the buyers, or in complete autonomy by 'oriented' management forms and managed by the people who are directly involved through rather simple procedures. What is interesting is that it can appeal to different social groups who will then choose their own management method. Therefore, redesigning urban spaces and even territories with positive shared values of living together respecting mankind and the environment appears as a possibility. It is outlined as a step of anthropologic evolution where values of sharing, tolerance and mutual assistance are choices that are economically advantageous (meaning in the government of the space in which we live) as it is based on a strongly shared ethical choice.

\section{REFERENCES}

[1] Delendi, M.L., Il Progetto di Paesaggio come Dispositivo Terapeutico, Gangemi Ed.: Rome, 2015.

[2] Jacobs, J., The Death and Life of Great American Cities, Random House: New York, 1961.

[3] Carson, R., Silent Spring, Houghton Mifflin: Boston, 1962.

[4] Delendi, M.L., Salvare Berlino, Gruppo Edicom: Legnano, 2007.

[5] Shumacher, E.F., Small is Beautiful, Economics as if People Mattered, Blond and Briggs: London, 1973.

[6] Meadows, D.H., Meadows, D.L., Randers J. \& Beherens, W.W., Limits to Growth, Universe Books: New York, 1972.

[7] Meadows, D.H., Meadows, D.L. \& Randers J., Limits to Growth: the 30-Year Update, Chelsea Green Publishing: White River Junction, VT, 2004.

[8] Latouche, S., Petit Traité de la Décroissance Sereine, Mille Et Une Nuits: Paris, 2007.

[9] Latouche, S., Vers une Société d'Abondance frugale. Contresens et Controverses sur la Décroissance, Mille Et Une Nuits: Paris, 2011.

[10] Beck, U., Risikogesellschaft. Auf dem Weg in eine andere Moderne, Suhrkamp: Frankfurt a.M., 1986.

[11] Jonas, H., Das Prinzip Verantwortung. Versuch einer Ethik für die Technologische Zivilisation, Suhurkamp: Frankfurt a.M., 1979.

[12] Addario, N., La Sociologia come Teoria dei Sistemi Sociali, in Italian Association of Epistemology and Systemic Methodology, 2010, available at www.aiems.eu

[13] Sopranzetti, C., Mazzolini, S. \& Gebaudo, P., Si può Spezzare l'Inerzia ? Movimenti Sociali Locali e Globali che propongono un'Alternativa, Round Table: FriulFuturForum, Udine, 4 February 2016.

[14] Delendi, M.L., Integrazione delle Infrastrutture Verdi nei Sistemi Infrastrutturali. Urbanistica Informazioni, 257, pp. 33-36, II, 2014.

[15] Delendi, M.L., Multifunzionalità degli Spazi Pubblici. Urbanistica Informazioni, 257, pp. 72-75, III, 2014.

[16] Delendi, M.L., Infratsrutture Verdi e Recupero di Aree Dismesse. Urbanistica Informazioni, 257, pp. 72-74, IV, 2014. 
[17] Mocca, F.D. \& Sepe, M. (eds), Green and Blue Infrastructures, Virtual, Cultural and Social Networks, 9 INU Study Day. Urbanistica Informazioni, 263, 2015.

[18] Baratta, A.F.L., Finucci, F., Gabriele, S., Metta, A., Montuori, L. \& Palmieri, V., Cohousing, Programmi e Progetti per la Riqualificazione del Patrimonio Esistente, ETS: Pisa, 2014.

[19] www.ecodistricts.org/about/vision-mission-values/

[20] Bianchetti, C. \& Sampieri, A., Antiurbanesimo Contemporaneo, available at www. planum.net/antiurbanesimo-contemporaneo

[21] Narne, E. \& Sfriso, S., L'Abitare Condiviso, le Residenze Collettive dalle Origini al Cohousing, Marsilio Editore: Venice, 2013.

[22] Lietaert, M., Cohousing e Condomini Solidali, Aam Terra Nuova: Florence, pp. 5-11, 2007.

[23] Chiodelli, F., Enclaves private a carattere residenziale: il caso del co-housing. Rassegna Italiana di Sociologia, 51(1), pp. 95-116, 2010.

[24] CO ventidue Milano- Il Cohousing ha fatto centro, Sede Arci Bellezza, 9 February 2016. http://www.cohousing.it/progetti.html\#progettiattivi

[25] www.thecollective.co.uk/

[26] www.krausfitch.com/wp-content/uploads/2013/02/Eco-Cohousing-Part-1.pdf

[27] www.cohousing.org

[28] Guidotti, F., Ecovillaggi e Co-housing, Ed. Aam Terra Nuova: Firenze, 2013.

[29] www.gen.ecovillage.org

[30] www.ecovillaggi.it 